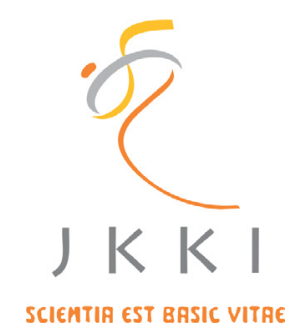

Jurnal Kedokteran dan Kesehatan Indonesia

Indonesian Journal of Medicine and Health

Journal homepage : www.journal.uii.ac.id/index.php/JKKI

\title{
Total phenolic content and antioxidant activities of binahong (Anredera cordifolia.)
}

Hari Susanti*1

${ }^{1}$ Department of Pharmacy, Faculty of Pharmacy, Universitas Ahmad Dahlan, Yogyakarta, Indonesia

Original Article

\begin{tabular}{l} 
ART ICLE I NF O \\
\hline Keywords: \\
Binahong, \\
antioxidant, \\
DPPH, \\
TPC \\
*Corresponding author: \\
susantihari@gmail.com \\
\hline DOI: 10.20885/JKKI.Vol10.Iss2.art9 \\
History: \\
Received: March 3, 2016 \\
Accepted: April 4, 2018 \\
Online: August 30, 2019 \\
\hline Copyright @2019 Authors. \\
This is an open access article \\
distributed under the terms \\
of the Creative Commons At- \\
tribution-NonCommercial 4.0 \\
International Licence (http:// \\
creativecommons.org/licences/ \\
by-nc/4.0/).
\end{tabular}

\section{ABSTRACT}

Background: Binahong plants are reportedly containing polyphenols, flavonoids, and steroid compounds. The content of polyphenols and flavonoids plays an important role as antioxidants. Research using the method of FRAP (Ferric Reducing Ability of Power) indicates that the antioxidant content of the binahongleaves extract is $3.68 \mathrm{mmol} / 100 \mathrm{~g}$ in dried leaves. This study offers new proof of antioxidant activity of all the aerial part of binahong.

Objective: This research aims to determine the total phenolic content from binahong extract and its ability as free radical scavenger using DPPH method.

Methods: The plant used in this research is every part of plants on the ground. The binahong extract is obtained by a maceration method with various solvents (hexane, chloroform, and methanol). Total phenolic content in the extract is spectrophotometrically determined with the Folin Ciocalteu reagent. Antioxidant activity assay is performed in vitro by the method of DPPH, with Gallic acid as a comparator. $\mathrm{ES}_{50}$ parameter is determined from the linear regression equation between the concentration of extracts and \% scavenging.

Results: The results showed that the total phenolic content of hexane, chloroform and methanol extract of Binahong was 8.54 $\pm 0.49 \mathrm{GAE}$ $\mathrm{mg} / \mathrm{g}, 17.30 \pm 0.47 \mathrm{GAE} \mathrm{mg} / \mathrm{g}$ and $32.5 \pm 1.11 \mathrm{GAE} \mathrm{mg} / \mathrm{g}$. Hexane extract, chloroform extract and methanol extract of Binahong have a free radical scavenger activity. The value of $\mathrm{ES}_{50}$ extracts of hexane, chloroform, methanol, and successive acid errors is $58.601 \pm 2.533 \mu \mathrm{g} / \mathrm{ml}, 446.219 \pm$ $2.268 \mu \mathrm{g} / \mathrm{ml}, 237.683 \pm 13.373 \mu \mathrm{g} / \mathrm{ml}$ and $2.058 \pm 0.002 \mu \mathrm{g} / \mathrm{ml}$.

Conclusion: The capability of the three of binahong extract as a free radicals DPPH scavenger were weaker than gallic acid.

Latar Belakang: Tanaman binahong dilaporkan mengandung senyawa polifenol, flavonoid, dan steroid. Kandungan polifenol dan flavonoid memiliki peranan penting sebagai antioksidan. Penelitian dengan menggunakan metode FRAP (Ferric Reducing Ability of Power) menunjukkan bahwa aktifitas antioksidan dari daun binahong .3,68 mmol/100 g pada simplisia daun kering. Penelitian ini akan mencari sebuah bukti baru aktivitas antioksidan semua bagian binahong yang berada di atas permukaan tanah.

Tujuan: Penelitian ini bertujuan untuk mengetahui seberapa besar kandungan fenolik total dari ekstrak binahong serta mengetahui kemampuan ekstrak binahong sebagai penangkap radikal bebas dengan menggunakan metode DPPH.

Metode: Bagian tanaman binahong yang digunakan pada penelitian ini adalah seluruh bagian tanaman yang ada diatas tanah. Ekstrak binahong diperoleh dengan cara maserasi bertingkat dengan menggunakan pelarutheksan, kloroform dan metanol. Kandungan fenolik total dalam ekstrak ditentukan secara 
spektrofotmetri dengan pereaksi Folin Ciocalteu. Uji penangkapan radikal bebas dilakukan secara in vitro dengan metode DPPH, dengan asam galat sebagai pembanding. Harga $E S_{50}$ ditentukan dari persamaan regresi linear antara konsentrasi ekstrak dan \% penangkapan.

Hasil: Hasil penelitian menunjukkan bahwa Kandungan fenolik total ekstrak heksan, kloroform

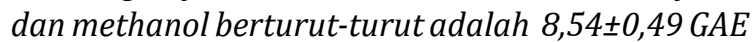
$\mathrm{mg} / \mathrm{g}, 17,30 \pm 0,47 \mathrm{GAE} \mathrm{mg} / \mathrm{g}$ dan 32,5 $\pm 1,11 \mathrm{GAE}$ $\mathrm{mg} / \mathrm{g}$. Ekstrak heksan, ekstrak kloroform ekstrak metanol binahong mempunyai kemampuan sebagai penangkap radikal bebas. Nilai $E S_{50}$ ekstrak heksan, kloroform, metanol dan asam galat berturut-turut adalah 583,601 $\pm 2,533 \mu \mathrm{g} / \mathrm{ml}, 446,219 \pm 2,268 \mu \mathrm{g} /$ $\mathrm{ml}, 237,683 \pm 13,373 \mu \mathrm{g} / \mathrm{ml}$ dan 2,058 $\pm 0,002 \mu \mathrm{g} / \mathrm{ml}$.

Kesimpulan: Potensi ketiga ektrak binahong sebagai penangkap radikal bebas DPPH lebih lemah dibanding asam galat.

\section{INTRODUCTION}

Free radicals may play a role in various degenerative diseases such as cancer, atherosclerosis, ageing, inflammation, diabetes, hair loss, and Parkinson's. ${ }^{1,2}$ The effects of free radicals can be mitigated if the body has enough antioxidants and by regulating diet, such as by consuming foods and drinks that contain a high level of antioxidants. Therefore, people are starting to change their lifestyles by using nature-sourced materials which are believed to be healthier and safer for the body. ${ }^{3}$

The human body is capable of producing limited amounts of endogenous antioxidants. However, the limited amount of antioxidants is not able to fight the increasing free radicals inside the body. Therefore, exogenous antioxidants are needed to fight the increase in free radicals. ${ }^{4}$

Antioxidants can eliminate, clean (scavenging), resist formation, or negate the effects of free radicals. ${ }^{4,5}$ There are 2 types of antioxidants; synthetic and natural antioxidants. Natural antioxidants have higher effectiveness but lower toxic properties compared to synthetic antioxidants. ${ }^{6}$ Therefore, the food and medicine industry has shifted to develop natural antioxidants.

Binahong (Anredera cordifolia) or Tenore Steen is found in South America and one of the interesting plants to study. Growing evidence suggests that the binahong plant has clinical potentials. Binahong leaves and rhizoma are known to be useful as a healing agent for scars, typhus, inflammation of the intestine, lowering uric acid, dysentery, and haemorrhoid. Binahong leaves contain triterpenoid saponins, flavonoid compounds, and ursolic acid.,8

Binahong plants need to be explored to obtain its active compounds of the antioxidants property. It is necessary to screen the antioxidant potential with some extraction methods and compound with various levels of polarity. Previous studies have shown that the ethanol extract of binahong leaves has antioxidant activity. ${ }^{9,10}$ Accordingly, this study using all parts of plants above ground with hexane (non-polar), chloroform (semipolar), and methanol (polar) extracts to obtain extracts tested for free radical scavenging activity. The results of this study suggest that the use of binahong can be optimized, especially in the health sector.

\section{METHODS}

Binahong plants were obtained from the Bantul Pleret area of Yogyakarta. Determination of plants was carried out in the Laboratory of Pharmaceutical Biology, Gadjah Mada University.

\section{Extraction procedures}

The process of extraction in this study was done by using a gradual maceration method. 20 $\mathrm{g}$ of dried powder from all parts of the Binahong plant above ground level was extracted with gradually organic solvents from non polar to polar organic solvents (hexane, chloroform and methanol). After maceration periods, the soaked powder-solvent mixtures were filtered by using Buchner funnel. The residue left in the funnel was re-extracted twice follow the same procedure and filtered. Each extract was concentrated and dried by by using rotary evaporator to obtain a thick extract.

\section{Antioxidant activity}

The free radical scavenging activity of hexane, chloroform, and methanol extracts of Binahong 
was measured using DPPH assay. The extracts were added into tubes containing $0,15 \mathrm{mM}$ methanolic DPPH solution. The reduction of absorbance at $516 \mathrm{~nm}$ was measured twice, before and 30 minutes after extracts were added into tubes.

Antioxidant activity is calculated by the following equation ${ }^{11}$ :

$$
\begin{aligned}
\% \text { Capture } & =\left[\left(\mathrm{A}_{\text {control }}-\mathrm{A}_{\text {test }} / \mathrm{A}_{\text {control }}\right] \times 100 \%\right] \\
\text { Note: } A_{\text {control }} & =\text { Control absorbance } \\
A_{\text {test }} & =\text { Control absorbance test sample }
\end{aligned}
$$

The concentration of extract needed to reduce absorbance by $50 \%$ from the initial state $\left(\mathrm{ES}_{50}\right)$ was determined by the regression equation between the percentage of capture and concentration. The smaller the value of ES50 means the greater the antioxidant power of the compound. As a comparison for this method used gallic acid, and all tests were replicated 3 times.

\section{Determination of total phenolic binahong extract}

Determination of Total Phenolic Content (TPC) was performed by visible spectrophotometry with Folin Ciocalteu reagent. This method is based on the formation of a blue complex that is read at a wavelength of $746 \mathrm{~nm}$. Gallic acid was used as a comparison. The third TPC value of the extract was expressed in Gallic Acid Equivalent (GAE) mg / g extract. A total of $10.00 \mathrm{mg}$ of each type of extract was dissolved in methanol to amount to $10.0 \mathrm{ml}$. Three hundred microliters of the extract solution were added to $1.5 \mathrm{ml}$ of the Folin-Ciocalteu reagent (which had been diluted 10 times). After settling for 3 minutes, the solution is added with $1.2 \mathrm{ml}$ of $7.5 \% \mathrm{Na}_{2} \mathrm{CO}_{3}$. The absorbance will be read at $765 \mathrm{~nm}$ after 1 hour. As a comparison used Galat acid (12) All tests were replicated 3 times. $\mathrm{ES}_{50}$ data and TPC content were statistically analyzed, namely, Anova continued with LSD with a 95\% confidence level using the SPSS program.

\section{RESULTS}

The extract yield obtained from each solvent was $1.2 \%$ Hexane; chloroform $4.2 \%$; and $6.3 \%$ methanol respectively. The ability of compounds as free radical scavengers is shown by a decrease in absorbance of DPPH at $\lambda 516.4 \mathrm{~nm}$. The results of antioxidant activity tests by DPPH method as shown in Table 1 and Figure 1 below:

Table 1. The results of antioxidant activity tests by DPPH

\begin{tabular}{lc}
\hline \multicolumn{1}{c}{ Sample } & ES $_{50} \pm$ SD $(\mu \mathrm{g} / \mathrm{ml})$ \\
\hline Gallic Acid & $2.058 \pm 0.002^{*}$ \\
Methanol extract & $237.68 \pm 13.373^{*}$ \\
Chloroform extract & $446.219 \pm 2.268^{*}$ \\
Hexane extract & $583.601 \pm 2.533^{*}$ \\
\hline Note: $\mathrm{n}=3^{*} \mathrm{p}<0.05$ &
\end{tabular}

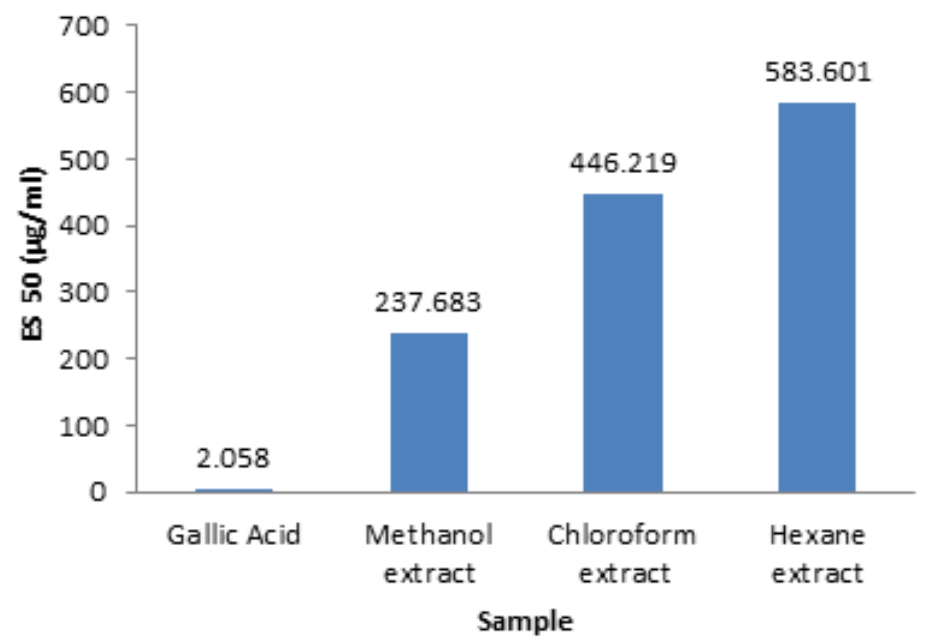

Figure 1. Comparison of $\mathrm{ES}_{50}$ between Gallic acid and binahong extract 
The results of determining the extract TPC content are presented in Figure 2.

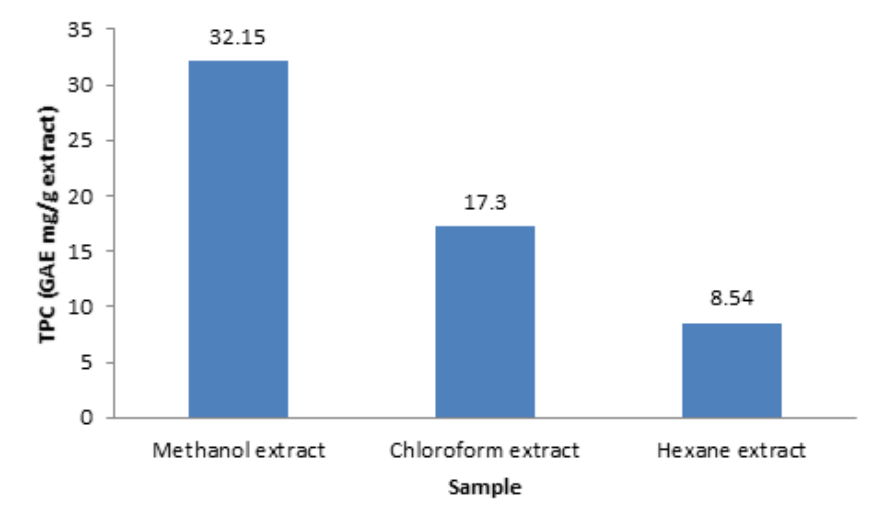

Figure 2. Profile of phenolic total Binahong extract

\section{DISCUSSION}

Figure 1 shows that methanol extract has the most powerful ability as the free radical scavenger compared to chloroform extract and hexane extract. Based on the $\mathrm{ES}_{50}$ value of methanol extract, the smaller the $\mathrm{ES}_{50}$ value of a substance, the greater its ability as a free radical scavenger. The results of this study are in line with another research which states that the methanol extract of binahong leaves has higher free radical scavenging activity than hexane extract. ${ }^{13}$ However, the ability of binahong extract as a free radical scavenger is still weaker than gallic acid. According to Blois criteria, those three extracts are in the inactive category because they have an $\mathrm{ES}_{50}$ value of more than $200 \mu \mathrm{g} /$ ml. ${ }^{14}$ Different from the previous research, this study uses not only the leaves but also all parts of the plant above ground level (both stems, young leaves, and old leaves). ${ }^{15}$ Moreover, we studied the content of flavonoids and the total antioxidant capacity of the ethanol extract of binahong leaves. Antioxidant test methods used were also different, in which this study uses the DPPH method while Selawa et al. using the FRAP method.

The results of TPC determination showed that methanol extract has the highest TPC content followed by chloroform extract and hexane extract. This shows that more polar solvents tend to find polyphenol compounds.
Based on these data, it is seen that there is a correlation between TPC content and its ability as a free radical scavenger with a correlation coefficient (R) value of 0.994 . Accordingly, recent research states that the TPC content, as well as its antioxidant potential of lampes leaf extract, is greater than the seed extract. ${ }^{16}$ This is supported by Büyüktuncel et al which suggests that antioxidant activity is strongly correlated with total phenolic content in red wine. ${ }^{17}$

\section{CONCLUSION}

The antioxidant activity of methanol extract was higher compared to chloroform extract and hexane extract. The total phenolic level oftotal methanol extracts was higher compared to chloroform extract and hexane extract.

\section{CONFLICT OF INTEREST}

None declare.

\section{Acknowledgement}

We thank to Universitas Ahmad Dahlan Research and Development Institute for funding assistance through the Independent Scheme Independent research grant.

\section{REFERENCES}

1. Surveswaran S, Cai Y-Z, Corke H, Sun M. Systematic evaluation of natural phenolic antioxidants from 133 Indian medicinal 
plants. Food Chemistry.. 2007 Jan 1 [cited 2019 Jul 16];102(3):938-53.

2. Kabel AM. Free radicals and antioxidants: Role of enzymes and nutrition. World Journal Nutrition and Health. 2014;2(3):35-8.

3. Hernani, Raharjo M. Tanaman obat berkhasiat. Jakarta Indonesia: Penebar Swadaya; 2005. 3, 56 p.

4. Lobo V, Pathil A, Pathak A, Chandra N. Free radicals, antioxidants and functional Foods : Impacton human health. Pharmacognosy Reviews. 2010;4(8):118-26.

5. Valko M, Leibfritz D, Moncol J, Cronin MTD, Mazur M, Telser J. Free radicals and antioxidants in normal physiological functions and human disease. The International Journal of Biochemistry \& Cell Biology. 2007 Jan 1 [cited 2019 Jul 16];39(1):44-84.

6. Soong YY, Barlow PJ. Antioxidant activity and phenolic content of selected fruit seeds. Food Chemistry. 2004;88(3):411-7.

7. Rahmawati F, Bintari SH. Studi aktivitas antibakteri sari daun binahong (Anredera cordifolia) terhadap pertumbuhan Bacillus cereus dan Salmonella enteritidis. Unnes Journal of Life Science. 2014;3(2):103-11.

8. Astuti SM, Sakinah A.M M, Andayani B.M $\mathrm{R}$, Risch A. Determination of saponin compound from Anredera cordifolia (Ten) Steenis plant (Binahong) to potential treatment for several diseases. Journal of Agricultural Science. 2011;3(4):224-32.

9. Fidrianny I, Ruslan Wirasutisna K, Amanda P. Senyawa antioksidan dari ekstrak etil asetat daun Binahong (Anredera cordifolia (Ten.) Steenis) dari Babakan Ciparay, Bandung Selatan, Indonesia. Acta Pharmaceutica Indonesia. 2013;26(1):26-30.

10. Parwati N, Napitupulu M, Diah A. Uji aktivitas antioksidan ekstrak daun binahong (Anredera Cordifolia (Tenore) Steenis) dengan 1,1-Difenil-2-Pikrilhidrazil (DPPH) menggunakan spektrofotometer UV-Vis. Jurnal Akademika Kimia. 2014;3(4):20613.

11. Philip M. The use of the stable free radical diphenylpicryl-hydrazyl (DPPH) for estimating antioxidant activity. Songklanakarin Journal of Science of Technology.
2004;26(2):211-9.

12. Alfian R, Susanti H. Penetapan kadar fenolik total ekstrak metanol kelopak bunga rosela merah (Hibbiscus sabdariffa Linn) dengan variasi tempat tumbuh. Pharmaciana. 2012;2(1):73-80.

13. Djamil R, Wahyudi PS, Wahono S, Hanafi M. Antioxidant activity of flavonoid from Anredera Cordifolia (Ten) Steenis Leaves. International Research of Journal of Pharmacy. 2012;3(9):241-3.

14. Puspita Sari E, Ningsih IY. Kapasitas antioksidan ekstrak buah salak (Salacca zalacca (Gaertn) Voss) varian gula pasir menggunakan metode penangkapan radikal DPPH. Pharmacy. 2016;13(01):116-26.

15. Selawa W, Revolta M, Runtuwene J, Citraningtyas G, Studi P, Fmipa F, et al. Kandungan flavonoid dan kapasitas antioksidan total ekstrak etanol daun binahong, Pharmacon, 2013;2(01):18-23.

16. Susanti H. In vitro antioxidant activity of lampes ( ocimum sanctum ) leaves and seeds ethanol extract using DPPH method. In: International Conference on Drug Development from Natural Resources. 2012. p. 269-74.

17. Büyüktuncel E, Porgalı E, Çolak C. Comparison of total phenolic content and total antioxidant activity in local red wines determined by spectrophotometric methods. Food and Nutrition Science. 2014;05(17):1660-7. 